\title{
Chronic manganese poisoning in the dry battery industry
}

\author{
A. M. EMARA, S. H. EL-GHAWABI, O. I. MADKOUR, and \\ G. H. EL-SAMRA \\ Cairo University and the National Institute for Industrial Safety and Health, \\ Heliopolis, Cairo, U.A.R.
}

\begin{abstract}
Emara, A. M., El-Ghawabi, S. H., Madkour, O. I., and El-Samra, G. H. (1971). Brit. J. industr. Med., 28, 78-82. Chronic manganese poisoning in the dry battery industry. A survey was carried out on 36 workers in the dry battery industry exposed to dust containing 65 to $70 \%$ manganese oxide. Eight $(22.2 \%)$ were found to have neuropsychiatric manifestations, six $(16.6 \%)$ had chronic manganese psychosis, one had left hemi-parkinsonism, and one had left choreoathetosis. An environmental study revealed a high concentration of manganese dust at the main working areas, far exceeding the accepted MAC. The manganese level in blood was almost within the normal range. Coproporphyrin in urine was normal. The electroencephalogram was abnormal in only two of the affected workers $(25 \%)$ but there was no association between this and the clinical manifestations or duration of exposure.

The concentration of manganese dust in air showed some association with the prevalence and rapidity of effect on workers according to their occupation. However, individual susceptibility was apparent. The shortest latent period was one year.
\end{abstract}

The history of poisoning with manganese dates back to 1837 when Couper described five cases in men grinding manganese dioxide in France and it continues to be the subject of reports from several parts of the world. It was not until 1919 that the definite relation between the epidemiological, clinical, and pathological effects of manganese poisoning on the central nervous system was established by Edsall, Wilbur, and Drinker (1919). Up to 1934,70 cases of manganese poisoning had been reported in the literature. By 1945 Fairhall was able to trace a total of 353 cases of manganese poisoning since the first cases reported by Couper. Rodier in 1955 described 150 cases.

The first cases in Egypt were described by Baader $(1932 a, b)$. In 1936,26 cases were reported by Nazif and 11 cases by Scander and Sallam. Three years later Baader (1939) reported another five cases of manganese poisoning. Abdel Naby and Has- sanein $(1963 ; 1965)$ reported 32 cases and 13 cases of chronic manganese poisoning, respectively.

Most of the cases reported in the literature have been miners. In the present study we report eight cases who had been occupationally exposed to manganese dioxide dust in the dry battery industry.

\section{Industrial process}

There are two main industrial operations in the dry battery industry; successively they are mixing and compressing.

\section{Mixing}

This is carried out in a large shed, $10 \times 16 \mathrm{~m}$, naturally ventilated by 16 small windows and without any other means of artificial ventilation. The operation begins with the unpacking of the raw material followed by the sieving of each constituent 
which is then weighed. Five workers are concerned with these primary processes. Mixing proper is twice performed by three mixers into which water is added for humidification, thus minimizing the evolution of dust. Dry battery powder consists of 65 to $70 \%$ manganese dioxide together with other substances ammonium chloride, zinc oxide, graphite, acetylene black, ammonium hydroxide, cerium-thorium nitrate, magnesium nitrate, mercuric chloride, and colophony. Fifteen workers are engaged in the mixing and remixing processes. Since 1966 the humidity in the mixing process has been intentionally raised from 10 to $15 \%$.

\section{Compressing}

This operation is carried out in a shed similar to that used for mixing and it is also only naturally ventilated. There are eight compressors with two workers on each. The mixed powder is added around a carbon rod and both are compressed. The workers use no personal protective equipment. They handle the powder and sometimes smoke during work without washing their hands. The subsequent processes are of no importance from the industrial medical point of view. They include rolling the battery rods, winding a piece of thread and adding wax, electrifica- tion of the rods, and, finally, finishing and wrapping processes.

\section{Material and technique}

A survey was made of 36 workers in a factory manufacturing dry batteries. In addition to the clinical examination, blood samples were taken from the eight workers considered to have chronic manganese poisoning after they had been transferred to new jobs at the same factory with minimal exposure to manganese dust. The manganese level in the blood was determined by spectrophotometry, after ashing, following the technique of Elkins (1959). No measurements were made on the blood of unaffected workers who continued at work.

An environmental study at the four main areas of dust exposure was undertaken using a midget impinger and following the technique described by Elkins (1959).

\section{Results}

The results of the clinical, laboratory, and environmental study are shown in Tables 1 and 2 .

The frequency of occurrence of the psychological symptoms of chronic manganese poisoning among our eight patients is shown in the Figure. The case reports of the two patients with physical manifestations are presented.

TABLE 1

Findings in Those Workers who showed Clinical Evidence of Chronic Manganese Poisoning

\begin{tabular}{|c|c|c|c|c|c|c|}
\hline $\begin{array}{l}\text { Serial } \\
\text { no. of } \\
\text { case }\end{array}$ & $\begin{array}{l}\text { Age } \\
(y r)\end{array}$ & $\begin{array}{c}\text { Occupational } \\
\text { exposure }\end{array}$ & $\begin{array}{c}\text { Latent } \\
\text { period } \\
(y r)\end{array}$ & $\begin{array}{c}\text { Mn level } \\
\text { in blood } \\
(\mu g / 100 \mathrm{ml})\end{array}$ & $\begin{array}{c}E E G \\
\text { findings }\end{array}$ & Clinical diagnosis \\
\hline $\begin{array}{l}1 \\
2 \\
3 \\
4 \\
5 \\
6 \\
7 \\
8\end{array}$ & $\begin{array}{l}28 \\
29 \\
29 \\
22 \\
32 \\
36 \\
30 \\
28\end{array}$ & $\begin{array}{l}\text { Compression } \\
\text { Mixing } \\
\quad,, \\
\text {,' } \\
\text { Compression } \\
\text { Mixing }\end{array}$ & $\begin{array}{r}16 \\
5 \\
3 \\
7 \\
7 \\
10 \\
13 \\
1\end{array}$ & $\begin{array}{l}0 \cdot 03 \\
0 \cdot 024 \\
1 \cdot 70 \\
0 \cdot 03 \\
0 \cdot 02 \\
2 \cdot 30 \\
0 \cdot 028 \\
0 \cdot 026\end{array}$ & $\begin{array}{l}\text { Abnormal } \\
\text { Normal } \\
\quad, \\
\text { Abnormal } \\
\text { Normal } \\
\quad, \\
\quad,\end{array}$ & $\begin{array}{c}\text { Chronic psychosis } \\
\text {," , } \\
,, \\
\text {, } \\
\text { Left hemiparkinsonism } \\
\text { Left choreo-athetosis }\end{array}$ \\
\hline
\end{tabular}

$\mathrm{Mn}=$ manganese

Abnormal = few bitemporal theta waves, slightly more on the left side, and a mild generalized cerebral dysrhythmia with a background activity of 7 to $9 \mathrm{c} / \mathrm{s}$.

TABLE 2

Dust Concentration at Main Working Areas

\begin{tabular}{|c|c|c|c|c|}
\hline Area & $\begin{array}{l}\text { No. of } \\
\text { samples }\end{array}$ & $\begin{array}{l}\text { Average concentration } \\
\left(\mathrm{mg} / \mathrm{m}^{3}\right)\end{array}$ & $\begin{array}{l}\text { Rate of deposition } \\
\quad\left(\mathrm{mg} / \mathrm{m}^{2} / \mathrm{hr}\right)\end{array}$ & Weight of $\underset{(\mathrm{Mng})_{2} \text { in sampies }}{\mathrm{MnO}}$ \\
\hline $\begin{array}{l}\text { Unpacking } \\
\text { Sieving } \\
\text { Mixing } \\
\text { Compressing }\end{array}$ & $\begin{array}{l}12 \\
12 \\
12 \\
12\end{array}$ & $\begin{array}{r}42 \cdot 2(36 \cdot 6-45 \cdot 7) \\
40 \cdot 2(37 \cdot 2-43 \cdot 8) \\
32 \cdot 6(28 \cdot 9-32 \cdot 8) \\
6 \cdot 8(6 \cdot 2-7 \cdot 2)\end{array}$ & $\begin{array}{ll}36 & (32-38) \\
32 \cdot 7 & (30-36 \cdot 2) \\
30 & (27-34) \\
6 & (5 \cdot 8-6 \cdot 3)\end{array}$ & $\begin{array}{r}28 \cdot 44 \\
25 \cdot 26 \\
21 \cdot 40 \\
4 \cdot 80\end{array}$ \\
\hline
\end{tabular}




\section{Case 7}

A male worker aged 30 years, married and with two children, was a previous addict to cannabis and a heavy cigarette smoker (40 cigarettes a day for 10 years). He had worked at compressing battery powder for 14 years without any previous occupation. His symptoms started 13 years after the start of exposure with a gradual onset of hallucinations and increased laughter. He was treated as a psychological case for one month, but he began to suffer from generalized paresis and marked disturbance of speech. His sexual potency was markedly increased. The course of the disease was progressive. On examination his complexion was normal, temperature $37^{\circ} \mathrm{C}$, pulse $104 /$ minute, blood pressure $130 / 80 \mathrm{mmHg}$. He had uncontrollable laughter and crying, euphoria, and mild amnesia. His speech was slurred and monotonous, his face masked, and he had micrographia and von Jaksch' (1901, 1907) or Cock's gait. The cranial nerves were intact and muscle tone was normal but he had diminished muscle power on the left side with exaggerated deep reflexes and lost abdominal reflexes on the same side. He had propulsion and retropulsion but coordination was not affected.
Case 8

A male worker aged 28 years, married with one child, had no special habits. One year after exposure to manganese dust in the manual mixing of dry battery powder he started to have painful involuntary movements in the left upper limb followed by the left lower limb. He was treated with anti-parkinsonism drugs without improvement. Five months later involuntary movements in the tongue developed. The movements occurred during sleep and awakened him. He could keep his balance and had no sphincteric disturbances, dysphagia, or regurgitation of food. There was no family history of a similar condition and no history of rheumatic fever, encephalitis or head injury. On examination he was of normal intelligence; the facial expression was not masked but he had involuntary movements in the left upper limb when at rest which became less on use. The movements were athetoid with flexion of the wrist, hyperextension of the metacarpophalangeal joints, pronation of the forearm and contractions in the shoulder muscles followed by the fingers and wrist with supination of the forearm. The left foot showed flexion and extension movements in the toes, especially the big toe. The tongue showed mild 
spontaneous movements on protrusion. There was no rigidity. The fundi, cranial nerves, motor power, sensations, reflexes, chest, heart, and abdomen were normal. The movements stopped almost completely following right stereotactic thalamic thermocoagulation. He was discharged and given benzhexol (Artane), $2 \mathrm{~g}$ three times a day, and was off sick for one month.

\section{Discussion}

The first manifestations of poisoning by manganese are usually subjective. Many exposed workers present peculiar psychic impulses and abnormal desires (Johnstone and Miller, 1960). Peñalver $(1955 ; 1957)$ points out that the detection of these strange characteristics is important in early diagnosis and removal of the individual from exposure. The clinical manifestations of chronic manganism have been well documented (Patty, 1963; Rodier, 1955; Whitlock, Amuso, and Bittenbender, 1966; von Oettingen, 1935) and its physiochemopathology was extensively reviewed by Cotzias (1958).

In the present survey eight workers showed various neuropsychiatric manifestations of chronic manganese poisoning, thus giving a prevalence of $22.2 \%$. Six of these had chronic psychosis. The commonest complaint was headache and it was often severe with no special localization or timing. It was associated in all six cases with an inverted sleep rhythm. This agrees with the findings reported by Peñalver (1955) and Rodier (1955). Sexual impotence or diminished libido was found in three of our cases. Peñalver (1955) reported impotence as one of the commonest manifestations of poisoning in Cuban miners drilling and blasting manganese ore. Sexual stimulation was found in our one case suffering from parkinsonism and this hypersexuality continued for more than one year without being followed by diminished libido.

Chronic psychosis due to manganese may or may not be followed by neurological manifestations. In the present survey, only one case of psychosis progressed to parkinsonism. In only one of our eight cases were neurological manifestations not preceded by psychic disturbances (case 8).

The manganese levels in blood are almost within normal range, particularly as six workers changed their original jobs and were not further exposed to manganese dust. The only two workers who continued in their original jobs (cases 3 and 6) showed levels of 1.7 and $2 \cdot 3 \mu \mathrm{g} / 100 \mathrm{ml}$ of blood (Table 1 ). The last figure may indicate a moderate manganese intoxication, according to Schürmann (1956). However, it is well known that manganese has no cumulative effect and is rapidly excreted from the body, hence the minor importance of blood manganese levels even in exposed workers (Patty, 1963).

The concentration of manganese dust was well above the threshold limit values for manganese set by the American Conference of Governmental Industrial Hygienists (1968) which has a ceiling value of $5 \mathrm{mg} / \mathrm{m}^{3}$. The relatively higher concentrations in the mixing operation might account for the relatively short latent period in affected workers compared with those in the compressing operation.

Only two out of eight cases $(25 \%)$ showed abnormal electroencephalographic changes. Apparently these changes are not early diagnostic criteria of chronic manganese poisoning. Furthermore, there is no definite correlation between electrcencephalographic and clinical manifestations. This agrees with the findings of Abdel Naby, Kayed, and Aref (1964).

In the present study many workers had been exposed for 10 years and more without developing chronic manganese poisoning whereas others exposed for only a few years developed manganism. The shortest latent period was one year, which is relatively short considering the nature of the occupation and the mode of exposure in the dry battery industry. Our findings confirm the statement of Peñalver (1955) that possibly in no other occupational disease is individual sensitivity more important than in manganism.

\section{References}

Abdel Naby, S. El Din, and Hassanein, M. (1963). Clinical study of chronic manganese poisoning in Egypt. Lecture delivered at the International Congress of Industrial Medicine, London.

, - (1965). Neuropsychiatric manifestations of chronic manganese poisoning. J. Neurol. Neurosurg. Psychiat., 28, 282-288.

- Kayed, K. S., and Aref, M. A. (1964). EEG induced fast activity in chronic manganese poisoning. Acta neurol. scand., 40, 259-268.

American Conference of Governmental Industrial Hygienists (1968). Threshold Limit Values of Airborne Contaminants for 1968, adopted at the 30th Annual Meeting, St. Louis, May 13, 1968.

Baader, E. W. (1932a). Manganvergiftungen in Elementefabriken. Arch. Gewerbepath. Gewerbehyg., 4, 101-116. (1932b). Manganismus eines Trimmers. Zbl. Gewerbehyg., 19 (n.s. 9), 1-3.

- (1939). Manganese (dust) poisoning. J. Amer. med. Ass., 113, 521.

Cotzias, G. C. (1958). Manganese in health and disease. Physiol. Rev., 38, 503-532.

Couper, J. (1837). On the effects of black oxide of manganese when inhaled into the lungs. Brit. Ann. Med. Pharm., 1, 41-42.

Edsall, D. L., Wilbur, F. P., and Drinker, C. K. (1919). The occurrence, course and prevention of chronic manganese poisoning. $J$. industr. Hyg., 1, 183-193.

Elkins, H. B. (1959). The Chemistry of Industrial Toxicology, 2nd ed., p. 358. John Wiley, New York.

Fairhall, L. T. (1945). Chronic manganese poisoning. Physiol. Rev., 25, 186-189.

Jaksch, R. von (1901). Ueber gehäufte diffuse Erkrankungen des Gehirns und Rückenmarks, an den Typus der multiplen Sklerose mahnend, welche durch eine besondere Aetiologie gekennzeichnet sind. Wien. klin. Rdsch., 15, 729-733. 
- (1907). Ueber Mangantoxikosen und Manganophobie. Münch. med. Wschr., 54, 969-972.

Johnstone, R. T., and Miller, S. E. (1960). Occupational Diseases and Industrial Medicine, pp. 305-308. Saunders, Philadelphia.

Nazif, M. (1936). Manganese as an industrial poisoning. J. Egypt. publ. Hlth Ass., 10, 1-20.

Patty, F. A. (1963). Industrial Hygiene and Toxicology, 2nd ed., Vol. 2, pp. 1079-1089. Interscience Publishers, New York.

Peñalver, R. (1955). Manganese poisoning. The 1954 Ramazzini Oration. Industr. Med. Surg., 24, 1-7.

- (1957). Diagnosis and treatment of manganese intoxication. Arch. industr. Hlth, 16, 64-66.
Rodier, J. (1955). Manganese poisoning in Moroccan miners. Brit. J. industr. Med., 12, 21-35.

Scander, A., and Sallam, H. A. (1936). A report on eleven cases of chronic manganese poisoning. J. Egypt. med. Ass., 19, 57-62.

Schürmann, D. (1956). Manganese poisoning in the preparation of fertilisers containing trace elements. $Z$. Arbeitsmed. Arbeitsschutz., 6, 106-116.

von Oettingen, W. F. (1935). Manganese: its distribution, pharmacology and health hazards. Physiol. Rev., 15, 175-201.

Whitlock, C. M., Jr., Amuso, S. J., and Bittenbender, J. B. (1966). Chronic neurological disease in two manganese steel workers. Amer. industr. Hyg. Ass. J., 27, 454-459.

Received for publication January 19, 1970

\section{The October (1970) Issue}

Short-term absence from industry. III. The inference of 'proneness' and a search for causes P. FroGgATT

Coronary heart disease among workers exposed to carbon disulphide S. Hernberg, T. Partanen, C-H. Nordman, AND P. Sumari

A long-term follow-up of respiratory symptoms and ventilatory function in a group of working men PETER HOWARD

Acute mercurial pneumonitis James Milne, Allen Christophers, and Pamela de Silva

Lead concentrations in human tissues P. S. I. BARRY AND D. B. Mossman

Excretion of lead and its biological activity several years after termination of exposure I. PŘ EROVSKÁ AND J. TeISINGER

Circadian excretory rhythms in night workers R. T. W. L. Conroy, A. L. Elliotr, AND J. N. Mills

Headaches and migraine in colour retouchers P. J. TAtLor, S. J. Pocock, S. A. Hall, and W. E. Waters

General practice workload and certification of illness during a coalfield strike J. E. LUNN, J. G. RIDER, W. H. R. WATERS, AND R. B. CHARNOCK

Renal damage from industrial arsine poisoning P. R. Uldall, H. A. KHAN, J. E. EnNis, R. I. McCallum, and T. A. Grimson

A simple method for the quantitative analysis of urinary trichloroethanol and trichloroacetic acid as an index of trichloroethylene exposure Masana Ogata, Yoshiko Takatsuka, AND Katsumaro TOMOKUNI

Notes and miscellanea

A monstrous growth: an historical note on carcinoma of the scrotum M. D. KIPLING, R. Usherwood, AND R. VARLEY

Book reviews

Current awareness

Index

A number of copies are still available and may be obtained from the Publishing Manager, British Medical Association, Tavistock Square, London WC1H 9JR price 22s. $6 d$. 